\title{
Review ofBiological Methods for Hazardous Waste Treatment
}

\author{
G. Sood ${ }^{1}$, N. Chitre ${ }^{2}$, K.C. Dabhadkar ${ }^{3}$ \\ ${ }^{1}$ (Department of Oils, Oleochemicals and Surfactants, Institute of Chemical Technology, India) \\ ${ }_{2}^{2}$ (Department of Pharmaceutical Sciences and Technology, Institute of Chemical Technology, India) \\ ${ }^{3}$ (Department of Chemical Engineering, Institute of Chemical Technology, India)
}

\begin{abstract}
About 9.3 million metric tons of hazardous waste generated has to be incinerated every yearwhich leave adverse effects on the environment. Biotechnology gives promising ways to not only disinfect and destroy the hazardous, toxic and infectious potential of the waste but also transforms it into material which can be reused. Vermicomposting is used to convert infectious biodegradable waste containing various pathogenic microorganisms to an innocuous waste. Cyanides are peculiar industrial wastes and they can be bio treated by Pseudomonas, achromobacter, flavobacterium, nocardia, bdellovibrio and mycobacterium. Fungal strains are a bioremediation tool for asbestos waste, a carcinogenic fibrous material. Biotechnological applications like Bioleaching, biosorption, phytoextraction and phytostabilisationetcetra help recover metals. Technology of engineering Halophiles and other extremophiles can be used to decontaminate highly toxic waste. Also, for the removal of reactive and hazardous compounds like phenols, hydrogen sulphide and anilines from industrial waste waters, a new peroxide based enzymatic method has been developed. Various biological methods were probed and significance of biotechnology in this field was assessed.
\end{abstract}

Keywords: Biotechnology, Hazardous waste, Waste management

\section{Introduction}

Every day huge amount of waste is generated, which is at present in need of attention. Recent developments in modern times have definitely raised our living standards. However, they have also contributed to manifold problems. Due to presence of various chemicals and toxic substances, disposal of waste is becoming a serious concern for the society. The volume of waste that is produced has increased manifolds in past decade. Therefore, it has become paramount in the world to take necessary measures to manage the rise in electronic waste as they consequently increase environmental pollution and health problems. Biotechnology finds application in treating wastewaters by various biological methods and solid waste disposal by many techniques in environmental science. Air emissions are also treated by biological methods. The various techniques based on principles of biotechnology in treatment of waste water are activated sludge, trickling filters, oxidation ponds, bio-filters and anaerobic treatment. Also, solid waste composting technique, bio filters and bio-sorption are few instances where biotechnology is applied in in environmental engineering. In all these methods, it is importance to find suitable microorganisms to degrade organic substances under favorable conditions to complete the treatment.

\section{Types of waste}

Solid waste, liquid waste and gaseous waste are generated in majority. Solid waste includes all the thrown away commodities from household dustbins to commercial waste disposals. These primarily can be classified into bio-degradable (organic waste) and non-bio-degradable (Plastic, glass etc.). Biodegradable household waste can be effectively treated using microorganisms and converted into useful products. Whilst, few advancements also suggest that microbes can be engineered to metabolize any and every kind of waste. In case of liquid waste streams, industrial waste waters are highly hazardous as they contain many toxic chemicals and heavy metals. Treatment of this water is crucially important before releasing it into water bodies and disturbing ecological health and balance. Biotechnology gives solution for environment friendly degradation of harmful heavy metals and toxic chemicals.

\section{Use of oxidative enzymes}

Enzymes show enormous potential of targeting specific pollutants for treatment. Better isolation and purification procedures have made enzymes more readily available and cheaper. The major advantages that enzymatic treatmenthasoverconventional treatments are:

1. Application to recalcitrant materials,

2. Operation on variable concentrations of contaminant.

3. Application over a wide temperature, $\mathrm{pH}$ and salinity range.

4. Needs of biomass acclimatization and many more. 
Recent research led to development of processes to treat wastewater using enzymes. Table 1 describes the wastewater treatment by peroxidases and phenoloxidases, dioxygenases, phenoloxidase-like (siderophores) and some aspects of soil remediation in order to assess the potential of immobilized enzymes \& their applications.

\section{Precious metal and heavy metal recovery}

The composition of e-waste is varying and it contains over a thousand different substances, which fall under the categories of organics and inorganics. Heavy metals form a significant part of inorganics, accounting toabout $40 \%$ of total inorganic fraction.E-waste contains various metals like lead, cadmium, arsenic, chromiumselenium, mercury and precious metals likegold,copper, silverand platinum. Manufacturing of mobile phones and personal computers consumes 3\% of gold and silver mined worldwide each year; $13 \%$ of the palladium and $15 \%$ of cobalt. Heavy metals are non-renewable and finite resources and so they are very valuable.

Bio-metallurgy can be used for recovery of metals in two ways- bioleaching and biosorption. For the recovery of silver and gold, the activity of leaching bacteria is applied only to remove interfering metal sulphides from

Table 1. Enzymes and their potential applications (N. Dur'an, E. Esposito / Applied Catalysis B:

Environmental 28 (2000) 83-99)

oresbefore cyanidation treatment (Morin et al., 2006). Bioleaching of metals involves use of live microorganisms (bacteria, fungi and algae) which incurs significant time. Moreover, live microorganisms are

\begin{tabular}{|c|c|c|}
\hline \multicolumn{3}{|c|}{ Enzymes and their potential applications } \\
\hline Enzymes & Source & Applications \\
\hline Peroxidases & $\begin{array}{l}\text { Artromyces ramosus } \\
\text { Plant materials }\end{array}$ & $\begin{array}{l}\text { Phenol, aniline degradation [1,5-11,14,17], chlorophenol degradation } \\
\text { [18,24,181] Kraft effluents decontamination [13,16,19], black liquor } \\
\text { decontamination [20], biosensor phenol determination [26], dewatering of } \\
\text { slimes [171] } \\
\text { Phenol degradation [12] Polymerization of humic acid [176] Polyaromatic } \\
\text { degradation [178,179,182] Herbicide degradation [183] } \\
\text { Water decontamination [123,191,195-199] }\end{array}$ \\
\hline Chloroperoxidase & Caldariomyces funago & Phenolic compounds oxidation [28-30] Biosensor chlorophenol detection [40] \\
\hline Lignin peroxidase & $\begin{array}{l}\text { Phanerochaete chrysosporium } \\
\text { Chrysonilia sitophila }\end{array}$ & $\begin{array}{l}\text { Aromatic compounds degradation }[41-43] \text {, phenolic materials degradation } \\
\text { [45-55], Kraft effluent remediation }[59] \\
\text { Kraft effluent decontamination }[13,16,44]\end{array}$ \\
\hline Manganese peroxidase & $\begin{array}{l}\text { Phanerochaete chrysopsorium } \\
\text { Nematolona frowardi e } \\
\text { Phebia radiata } \\
\text { Lentinula edodes }\end{array}$ & $\begin{array}{l}\text { Phenols and lignins degradation }[31,63,66] \text {, pentachlorophenol degradation } \\
\text { [64], dyes degradation }[65,68] \\
\text { Lignins degradation }[67] \\
\text { Chlorophenol degradation }[69,70] \text {, diuron degradation [193] }\end{array}$ \\
\hline Tyrosinase & Agaricus bisporus & $\begin{array}{l}\text { Biosensor phenol [78-80,96], phenols and amines degradation [86,93], } \\
\text { xenobiotic compound removal [87], catechol oxidation [89], phenolic } \\
\text { compounds polymerization [190] } \\
\text { Catechol oxidation [92] }\end{array}$ \\
\hline Laccase & $\begin{array}{l}\text { Trametes hispida } \\
\text { Pyricularia oryzae } \\
\text { Trametes versicolor } \\
\text { Cerrena unicolor } \\
\text { Pycnoponis cinnabarimus } \\
\text { Plant materials }\end{array}$ & $\begin{array}{l}\text { Analytical biosensors [103,140-145] } \\
\text { Dyes decoloration [107] } \\
\text { Azo-dyes degradation [116] } \\
\text { Textile effluent degradation, chlorophenols [118,125,135], urea derivatives } \\
\text { degradation [185] } \\
\text { Phenol detoxifying [120], 2,4-dichlorpenol degradation }[186,187] \\
\text { Benzopyrenes degradation [129] } \\
\text { Chlorophenols [122-124], xenobiotic binding to humus [122,123,172] }\end{array}$ \\
\hline Catechol dioxygenases & $\begin{array}{l}\text { Comamonas testosteroni } \\
\text { Pseudomonas pseudoalacaligenes }\end{array}$ & $\begin{array}{l}\text { Biosensor catechol determination [147] } \\
\text { Chlorophenol oxidation [148], diuron degradation [192] } \\
\text { Polychlorinated biphenyls, chlorothanes [149-151] }\end{array}$ \\
\hline Phenoloxidase-like & $\begin{array}{l}\text { Gloeophyllum trabeum } \\
\text { Trametes versicolor } \\
\text { Phanerochaete chrysosporium } \\
\text { Thenmoascus aurantiacus }\end{array}$ & $\begin{array}{l}\text { Kraft effluent decontamination [167] } \\
\text { Chlorinated compounds degradation [168] } \\
\text { Kraft effluent }[157,164,165]\end{array}$ \\
\hline
\end{tabular}

subject to metal toxicity and other chemicals. This calls for further development in the area of bioleaching. 
The advantages of biosorption are: (i) non-living biomass are not subject to toxicity limitations; (ii) The cultivation of biomass can be done with inexpensive nutrients and without aseptic conditions .(iii) time saving process; (iv) cheap source of biomass available; ( $v$ ) can be operated at wider range of $\mathrm{pH}$, temperature and target compound concentration if suitable bio sorbent is taken.

Development in the technology of various resins has accelerated their use for treatment of heavy metals. Particularly, on a large scale use of zeolites has been successful for this purpose. Biosorption of metals and treatment with bacteria immobilized packed beds are the most prominent biological methods of treatment of hazardous metal wastes. Hawari et al. illustrated the use of anaerobic granules for biosorption by studying lead (II), cadmium (II), copper (II) and nickel (II). After the waste containing these metals was treated with the catalyst, binding capacity became equivalent to those obtained by commercial resins. The most important advantage of this type of biosorption is its particular shape, compact porous structure, excellent settling ability and high mechanical strength. Wang et al. studied saccharomyces cerevisiae as media for biosorption of heavy metals by. It was found that the yeast has only mediocre capacity for metal uptake as compared to other fungi but it can be easily cultivated and gives a large by-product of fermentation. Heavy metals can be separated from biologically degradable compounds in a sewage sludge by extraction with organic acids (Veeken and Hamelers, 1999). The $\mathrm{pH}$ needs to be maintained at mildly acidic conditions (between 3 and 5). Characteristics of medicagosativa (alfalfa) to bind nickel ions was studied by Gardea-Torresdey et al. (1996). Alfalfa was chosen owing to its high tolerance to concentrated metal contamination. It is found to grow in heavy metal contaminated waters. Cattle graze metal contaminated plants and accumulate toxic metals. These biological systems were studied. Dead systems were preferred because they do not degrade due to toxicological effects of high concentrated contaminants. They were not pre-treated to maintain the biological activity. Since immobilization is found to be efficient in metal removal, method utilizing alfalfa only was combined with it. It was found that binding of nickel to alfalfa is $\mathrm{pH}$ dependent. In addition to this, the binding is quick and stable. Similar trend was found for the binding of copper ions, which might be the result of ion exchange.

\section{Other methods using biotechnology}

\subsection{Activated sludge Treatment}

An activated sludge wastewater treatment system has at least four components; an aeration tank, a settling tank (clarifier), a return sludge pump and a system of introducing oxygen into the aeration tank. Wastewater, irrespective of if it is pre-treated or not, enters the aeration tank and mixes with microbes suspended in the presence of oxygen. The microbes metabolize the organic pollutants in the waste water. After spending some time equal to the hydraulic residence time in the aeration tank, the mixed liquor flows to the next step i.e. clarifier, where the solids (Mixed Liquor Suspended Solids- MLSS) are separated from the bulk liquid by settling. Then effluent which is clarified exits this system. The settled solids are recovered from the bottom of the clarifierand some fraction of these solids is recycled to the aeration tank and the remaining is discarded as waste. This gives the ability to control the average time of residence formicroorganisms to remain in the reactor, called the sludge retention time (SRT) or mean cell retention time (MCRT). Those MLVSS (Mixed Liquor Volatile Suspended Solids) solids that return to the tank are starved microbesseparated from untreated wastewater for a delayed period and are called activated.

\subsection{Trickling Filters}

Widely used to treat waste, this is a biological treatment method involving fixed film which is designed to reduce BOD and suspended solids. A trickling filter consisting of a rotating distribution arm evenly distributes liquid waste water over a bed of fist-sized rocks, other coarse materials, or synthetic media. The spaces available in-between the media allows air to circulate and maintain aerobic conditions. These spacesallow wastewater to trickle down around and over the media. Biological slime layer absorbs and consumes the wastes trickling through the bed and thus covers the media material. The organisms thatdoes aerobic decomposition of the solids, produce more such organisms and waste that either becomes part of the slime or is discharged into the wastewater on the media. This slime may consist of bacteria, algae, protozoa worms, snails, fungi and insect larvae or multiple of them. The accumulating slime occasionally sloughs off (sloughing) individual media materials and is collected at the bottom of the filter, along with the treated wastewater and passed on to the secondary settling tank where it is removed.

\subsection{Membrane Bio-Reactors}

Membrane bioreactors (MBRs) are becoming increasingly popular due to their various advantages in wastewater treatment. Their advantages are flexibility of operation, ability to attain higher sludge age and consequently, less sludge production and higher nitrification and denitrification rates (Ahmed et al., 2008). Some disadvantages of this system include frequent membrane monitoring and maintenance requirements, relatively high running costs and there is a limitation as to the pressures, temperatures and $\mathrm{pH}$ to which the 
system can be exposed (Dobson and Burgess, 2007). In addition to treatment of waste water, membrane bioreactors are also used for the production of amino acids, antibiotics, anti-inflammatories, anticancer drugs, vitamins, optically pure enantiomers and isomers.

\section{Use of vermicomposting to treat biodegradable medical wastes}

Wastes generated in the hospitals are very dangerous and need to be disinfected completely prior to their disposal. Study has shown that the infected waste which is biodegradable in nature can be disinfected by using the process of vermicomposting. This technology does not cause any negative impact on the surrounding or on human health. Vermicomposting comprises of the producing the compost by breeding the earthworms which feed on the waste and in this process the continuously turn, fragment and aerate the waste which leads to biooxidation. This results in a homogenous product which is like humus and is nutritive in nature and can be used as plant manure very effectively. On assessing the ability of vermicomposting, it was concluded that a coliform, non-pathogenic bacteria citrobacterfreundii was isolated instead of E. coli which was present previously in waste. These organisms are non-pathogenic in nature. It was also established that the earthworms did not just hasten the phenomenon of composting but they also activated the composting and helped in decreasing the net content of the infected waste. The resultant manure that was formed could thus be useful as a plant nutrient.

Figure

\section{Treatment of}

Ma et al. (2006) studied the removal of H2S from waste gases with the help of an activated carbon bioreactor. Using packed Granular Activated Carbon (GAC), the removal efficiency of the gas was about $98 \%$. The advantages of using immobilized cell reactors in the process are the low capital required, low operating costs, less energy requirements, no addition of chemicals or fuels is needed and the process is environmental friendly and so publicly accepted [Bohn, 1992; Delgado et al., 1999]. In using such a bioreactor, the gas is passed through packed bed of biomass supported on matrices of compost or humid earth, polyvinyl alcohol or sewage. The biodegradable volatile organic matter is absorbed and oxidized to water, carbon dioxide and sulphates. The packing is seeded with microbes degrading H2S. The disadvantage of using soil as a packing medium is that it might lead to clogging causing low pressure loss of bioreactor. The GAC is inoculated with cells and thus have more uniform surface area, good resistance to crushing, better operating control, pressure drop and can be maintained at desired $\mathrm{pH}$. Additionally, it provides higher pollutant absorbing capacity. The strain of bacteria used to inoculate GAC is thiobacillusdenitrifans, which has great potential to metabolize $\mathrm{H} 2 \mathrm{~S}$ with fast oxidation rate. The adsorption using this strain by GAC was studied by the plate counting method. It was found that the number of bacteria increased by up to $4 \times 10^{8}$ per milliliter of the sample. This resulted was compared with the number of bacteria found when no GAC carrier was used.Bio filtration using packing systems for separation of H2S fromoff gas present in waste water was studied extensively by Chouari et al. (2015). They studied microbial diversity present within two different H2S bio filtration systems, one packed with pozzolan and the other packed with marble. It was found that the sulphate concentration of $\mathrm{H} 2 \mathrm{~S}$ increased when marble bio filter was used and thus higher efficiency of separation was achieved. In a similar study, the bio filter packed with volcanic rocks was found to be more efficient than ceramic granules [Li et al., 2012]. The results were more consistently higher at different ranges of empty bed residence times. 
Malhautier et al. studied the characteristics of using granulated sludge as a packing material in air biofiltration. The air was loaded with a mixture of ammonia and H2S. The packing showed greater efficiency towards removal of $\mathrm{H} 2 \mathrm{~S}$ than ammonia. The $\mathrm{H} 2 \mathrm{~S}$ in the mixture was oxidized to sulphates and sulphur while ammonia was oxidized to nitrites and nitrates. In another study by Tang et al., gas containing triethyl amine (TEA) was studied in a bio filter. Sieved compost and chaff particles were used as filter which also immobilize bacteria. The concentration of the gas was found to decrease throughout the length of the filter. Thus, they concluded that the required length of the filter can be calculated from the degree to which the gas is required to be purified.

On the other hand, Chung et.al. (2001) studied the bio treatment of a mixture of H2S and ammonia gases by fluidized bed reactor. Packing used was a mixture of pseudomonas putida for treating $\mathrm{H} 2 \mathrm{~S}$ and arthrobacteroxydansfor treatment of ammonia. It was found that the efficiency for removal of $\mathrm{H} 2 \mathrm{~S}$ was more than $95 \%$ in all possible ratios of gases whenever the inlet $\mathrm{H} 2 \mathrm{~S}$ concentration was lesser than $30 \mathrm{ppm}$. Efficiency in the case of ammonia was always greater than $95 \%$ when the concentration of inlet ammonia was lesser than $100 \mathrm{ppm}$. Cox et al. (2002)compared using a fluidized bed reactor with a tricking bed reactor for cotreatment of $\mathrm{H} 2 \mathrm{~S}$ and toluene. The operation efficiency was similar for both the gases but a trickling bed reactor usually took only a few days for start-up.

\section{Advantages of Bioremediation}

On the basis of the situation and the type of the site, bioremediation offers numerous advantages over the general techniques used to treat waste like incineration, etc.

1. Minimum Disruption: Bioremediation generally involves only minimal, if any, physical disruption of a site. This is of great importance on beaches where the other technologies used to render the beaches clean like high and low pressure spraying and raking of congealed oil can cause damage to the natural flora and fauna that dwells on the beach.

2. Permanency: Using biotechnology, microorganisms convert the wastes into innocuous substances like carbon dioxide and water. Therefore there is absence of toxic waste that is generally left behind to further treat. For those wastes that cannot be totally mineralised by the biological action, biodegradation will cause the transition of the hazardous chemicals into stable and less toxic compounds.

Public Acceptance: In-situ bioremediation offers a process that reduces the hazards of handling toxic wastes and transporting them from one site to another. It also offers the public with a choice of treatment that will rely on natural degradation which will transform the hazardous wastes into compounds like water. Thus the design of the bio treatment system is non-threatening.

\section{Barriers to the commercialization of bioremediation}

Despite the numerous advantages that are offered by bioremediation we have major barriers that hinder the use of biotechnology in bioremediation.

Research Barriers: A lot needs to be studied and learned regarding the scientific foundation of bioremediation. The wastes that occur can take various forms, and are continuously subjected to varying environmental conditions. Thus, the kind of waste material at the site of concern along with the features of the site needs to be carefully determined prior to bioremediation of that site. Numerous targets can be considered for bioremediation like oil spills, industrial effluents, dump sites, radioactive wastes etc. However to understand how feasible biotechnology will be in the management of these wastes, great scientific and technical areas need to be explored and understood along with microbial physiology, biochemistry, genetics and the microenvironment in which the treatment needs to be effective.

Technical Barriers: Bioremediation generally is a slower process than the techniques that are employed more conventionally. Also it must be specifically tailored in accordance to the type of the waste and site every time. Each site is unique and has aspects that need special attention. Thus, various technicalities are involved when bioremediation is involved.

Regulatory Barriers: The major barrier lies when answering 'how clean is clean'. In some cases, the biological methods may achieve a health based standard, but will leave higher residues in comparison with the conventional methods like incineration.

\section{Conclusion}

Granular Activated Carbon (GAC) was found to be the best packing for separation of H2S using a bio filter. The concentration of microbes became constant after a certain amount of packing. Granular sludge, though efficient, is not as efficient as GAC. The choice of reactor tobe used for biological treatment of mixture of gases prominently composed of $\mathrm{H} 2 \mathrm{~S}$ depends on the quantum of $\mathrm{H} 2 \mathrm{~S}$ to be treated. Bio filters, with all types of packings are more efficient for $\mathrm{H} 2 \mathrm{~S}$ removal than ammonia removal. However, ammonia is removed more 
effectively than $\mathrm{H} 2 \mathrm{~S}$ by fluidized bed reactors. Using alfalfa for removal of nickel ensured removal efficiency as high as that obtained by commercial resins in some cases. Moreover, the efficiency increased when alfalfa packing was used along with immobilized cell reactor. The percent of nickel that bonded increased non-linearly with $\mathrm{pH}$, obtaining a constant value after a certain $\mathrm{pH}$.

In terms of economic and environmental benefits, biotechnology can be applied on various arenas like industry and agriculture. The processing of products is less expensive and product quality is enhanced. It is possible to evaluate various wastes around us by microbiological processes. Today, numerous microbiological waste processing projects can be conducted at high scale. For example, wastes that are solid in nature containing high organic substances are used for obtaining methane. Consequently, a new energy resource arises. In treating industrial and municipal wastewaters, various microbiological methods such as sludge that is activated, oxidation ponds, membrane bioreactors are used successfully. Wastes belonging to municipality and industries (liquid, solid and gaseous) that constitute environmental pollution and threaten public health must be treated. In the removal of these types of contaminants, cost of the project will be less important thereby promoting biotechnological applications.

\section{Journal Papers:}

\section{References}

[1]. Ma, Y., Zhao, J., \& Yang, B. (2006). Removal of H 2 S in waste gases by an activated carbon bioreactor. International biodeterioration\& biodegradation,57(2), 93-98

[2]. Bohn, H. (1992). Consider biofiltration for decontaminating gases. Chemical Engineering Progress, 88(4), 34-40

[3]. Delgado, S., Alvarez, M., Rodriguez-Gomez, L. E., \&Aguiar, E. (1999). H 2 S generation in a reclaimed urban wastewater pipe. Case study: Tenerife (Spain). Water Research, 33(2), 539-547.

[4]. Chouari, R., Dardouri, W., Sallami, F., Rais, M. B., Le Paslier, D., \&Sghir, A. (2015). Microbial analysis and efficiency of biofiltration packing systems for hydrogen sulfide removal from wastewater off Gas. Environmental Engineering Science, 32(2), 121-128.

[5]. Li, J., Ye, G., Sun, D., Sun, G., Zeng, X., Xu, J., \& Liang, S. (2012). Performances of two biotrickling filters in treating H2Scontaining waste gases and analysis of corresponding bacterial communities by pyrosequencing. Applied microbiology and biotechnology, 95(6), 1633-1641.

[6]. Malhautier, L., Gracian, C., Roux, J. C., Fanlo, J. L., \& Le Cloirec, P. (2003). Biological treatment process of air loaded with an ammonia and hydrogen sulfide mixture. Chemosphere, 50(1), 145-153.

[7]. Tang, H. M., Hwang, S. J., \& Hwang, S. C. (1996). Waste gas treatment in biofilters. Journal of the Air \& Waste Management Association, 46(4), 349-354.

[8]. Chung, Y. C., Huang, C., Liu, C. H., \& Bai, H. (2001). Biotreatment of hydrogen sulfide-and ammonia-containing waste gases by fluidized bed bioreactor. Journal of the Air \& Waste Management Association, 51(2), 163-172.

[9]. Cox, H. H., \&Deshusses, M. A. (2002). Co-treatment of H 2 S and toluene in a biotrickling filter. Chemical Engineering Journal, 87(1), 101-110.

[10]. Hawari, A. H., \& Mulligan, C. N. (2006). Biosorption of lead (II), cadmium (II), copper (II) and nickel (II) by anaerobic granular biomass. Bioresource technology, 97(4), 692-700

[11]. Wang, J., \& Chen, C. (2006). Biosorption of heavy metals by Saccharomyces cerevisiae: a review. Biotechnology advances, 24(5), 427-451.

[12]. Veeken, A. H. M., \&Hamelers, H. V. M. (1999). Removal of heavy metals from sewage sludge by extraction with organic acids. Water Science and Technology, 40(1), 129-136.

[13]. Gardea-Torresdey, J. L., Tiemann, K. J., Gonzalez, J. H., Cano-Aguilera, I., Henning, J. A., \& Townsend, M. S. (1996). Removal of nickel ions from aqueous solution by biomass and silica-immobilized biomass of Medicagosativa (alfalfa). Journal of hazardous materials, 49(2), 205-216.

[14]. Shuchi Patel and AvaniKasture* E (Electronic) Waste Management using Biological systems- C. G. Bhakta Institute of Biotechnology, UkaTarsadia University, Maliba Campus, BardoliMahuva Road, Tarsadi, Dist. Surat, Gujarat, India. 394350.

[15]. Jin Yin, Jin-Chun Chen, Qiong Wu, Guo-Qiang Chen, Halophiles, coming stars for industrial biotechnology- MOE Key Lab of Bioinformatics, School of Life Science, Tsinghua-Peking Centre for Life Sciences, Tsinghua University, Beijing 100084, China.

[16]. Nelson Durán(a) Elisa Esposito(b), Potential applications of oxidative enzymes and phenoloxidase-like compounds in wastewater and soil treatment, 0926-3373/00/\$ - see front matter (C) 2000 Elsevier Science Viraja Bhat*, Prakash Rao, Yogesh Patil, Development of an integrated model to recover precious metals from electronic scrap - A novel strategy for e-waste management- International Conference on Emerging Economies - Prospects and Challenges(ICEE-2012)

[17]. HanifeBüyükgüngör- The role of biotechnology on the treatment of wastes, African Journal Of Biotechnology · January 2009

[18]. Effects of Vermicomposting on Microbiological Flora of Infected Biomedical Waste Umesh B Mathur* , Lalji K Verma**, Jitendra N Srivastava****

[19]. 2. Dominguez J Edwards CA and Subler S. A comparison of vermin-composting and composting. Biocycle, April 1997, 57 - 5

[20]. Ehrlich, H.L., and Brierly, C. (eds.), Environmental Biotechnology: Microbial Mineral Recovery (New York NY:McGraw Hill, 1990).

[21]. Foster, M. S., et al., "To Clean or Not To Clean: The Rationale, Methods, and Consequences of Removing Oil From Temperate Shores," The Northwest Environmental Journal, vol. 6, 1990, pp. 105-120.

[22]. Omenn, G.S. (cd.), Environmental Biotechnology: Reducing Risks from Environmental Chemicals Through Biotechnology (New York NY: Plenum Press, 1988). 